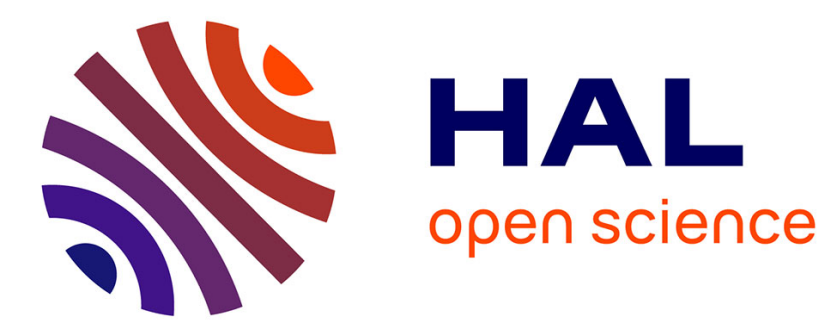

\title{
My own private England - the madness of James Tilly Matthews and of his times
}

\author{
Akihito Suzuki
}

\section{To cite this version:}

Akihito Suzuki. My own private England - the madness of James Tilly Matthews and of his times. History of Psychiatry, 2005, 16 (4), pp.497-502. 10.1177/0957154X05060649 . hal-00570833

\section{HAL Id: hal-00570833 \\ https://hal.science/hal-00570833}

Submitted on 1 Mar 2011

HAL is a multi-disciplinary open access archive for the deposit and dissemination of scientific research documents, whether they are published or not. The documents may come from teaching and research institutions in France or abroad, or from public or private research centers.
L'archive ouverte pluridisciplinaire HAL, est destinée au dépôt et à la diffusion de documents scientifiques de niveau recherche, publiés ou non, émanant des établissements d'enseignement et de recherche français ou étrangers, des laboratoires publics ou privés. 


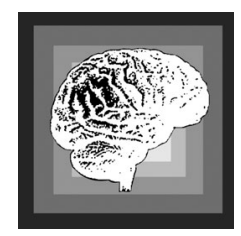

Essay Review

\title{
My own private England - the madness of James Tilly Matthews and of his times
}

\author{
AKIHITO SUZUKI* \\ Keio University
}

Mike Jay. The Air Loom Gang: The Strange and True Story of James Tilly Matthews. His Visionary Madness and his Confinement in Bedlam. London: Bantam Books, 2003. Pp. 347. ISBN 0-553-81485. $£ 7.99$.

Greg Hollingshead. Bedlam. Toronto: HarperCollins Publishers Ltd, 2004. Pp. 479. ISBN 0-00-200557-3. \$34.95.

Psychiatrists and historians used to quarrel bitterly over the territory of the history of psychiatry: which profession is the legitimate storyteller of psychiatry's past? Although a handful of die-hard belligerents from both sides continue the war, the futility of such a territorial dispute is becoming increasingly obvious. If we look around, the history of psychiatry in a broad sense is studied widely, far beyond the confines of the disciplines of history and psychiatry. Stories about mental illness and psychiatry in the past are now told by people with various backgrounds, and are listened to by a wider audience. Novels and films depicting madness in the past have flooded the contemporary cultural scene. Some of them are mega-hits: a novel depicting shell-shocked soldiers and their doctor won a Booker Prize in 1995; a film featuring a mad pianist won multiple Oscars in 1996; a similar feat was repeated in 2001 by another film about a schizophrenic Nobel laureate. Episodic depictions of mental illness in contemporary cultural canons and bestsellers are countless. Harry Potter's visit to the hospital ward for

* Address for correspondence: School of Economics, Keio University, 4-1-1 Hiyoshi, Yokohama 223-8521, Japan. Email: asuzuki@hc.cc.keio.ac.jp 
incurably insane wizards is just the tip of a huge iceberg. Telling a story of mental illness and its past has outgrown the territory under previous disputes, and neither historians nor psychiatrists can claim a monopoly. The history of psychiatry has become the talk of the town.

Narratives of mental illness have permeated contemporary culture because of many complex factors which cannot be discussed here. The effect of this permeation is, however, relatively straightforward: it has resulted in the steady integration of the discourse on mental illness into the language of the public sphere. Mental illnesses have now become one of the vital keys through which people understand themselves and others, their own society and that of others. Despite the ongoing ferocious professionalization of psychiatry, mental illness has continued its inroad into popular culture and people's consciousness. Befitting the post-Parsons and post-modern medicine model which instructs us to be 'patient-centred', the major focus of the contemporary discourse on mental disease is the patient rather than the doctor. Accordingly, for historians, there are a handful of 'star patients', just as Charcot had a couple of star hysterics at the Salpêtrière. Among those with suicidal tendencies, van Gogh and Sylvia Plath are two celebrities, helped by their stature in art and literature. Among an array of celebrated cases within the psychoanalytic canon, Daniel Paul Schreber is arguably the king of historical schizophrenics, and historians, philosophers and literary critics, as well as psychiatrists, have lavished attention on his Memoirs.

No less alluring, but far less studied is James Tilly Matthews, a tea merchant in London in the late eighteenth and early nineteenth centuries. Matthews' insanity was recorded as a case study by John Haslam, then an apothecary at the Bethlem Hospital, where Matthews was admitted in 1797 and stayed almost until his death in 1815. The key text, Haslam's Illustrations of Madness (1810), was edited and published by the late Roy Porter in 1988 with illuminating and detailed introduction. What makes Matthews particularly interesting is the fact that he lived at the heart of two revolutions. First, he was closely involved into a diplomatic mission to the French government in Revolutionary Paris in the 1790s and then became embroiled in the political melting-pot of turn-of-the-century London. Second, Matthews was a patient exactly when Pinel, Tuke and others were introducing drastic reforms into psychiatric hospitals, although it is now unfashionable to speak of these reforms in psychiatry as 'revolutionary'. A book on Matthews has thus long been overdue. At last, we have two books on him almost simultaneously: Mike Jay's The Air Loom Gang and Greg Hollingshead's Bedlam. Significantly, neither of the two works is intended for a narrowly academic readership. Jay has written a history book for general readers, while Hollingshead's work is a historical novel, a genre that has enjoyed renewed popularity in the last couple of decades. So Matthews has come out of relative obscurity and is going to be one of the icons of mental patients in the contemporary culture of our times. 
Although Jay's book lacks footnotes and other academic apparatus, it has almost all the merits of an excellent historical work. It is based on substantial research into English and French archives, which is a rare feat among academic historians of psychiatry who most commonly operate within national boundaries. It exhibits a solid grasp of the relevant historical background, both of the volatile Anglo-French politics and the dynamic situation of a nascent psychiatric specialty. Its analysis of mental illness, maddoctoring and the inner world of the patient is original and intellectually thrilling. Not least, the narrative is immensely readable. Jay has excavated hitherto little known episodes in the tumultuous life of Matthews, such as his plan of growing cabbages in hothouses with the aid of human manure brought from Parisian cesspools (a plan that anticipated Edwin Chadwick and irrigated sewage farms along the Seine from the 1860s on). The well known irony of Matthews' designs for the architecture of the reformed new Bethlem (Bethlehem) Hospital are given a fresh in-depth analysis. Most impressively, Jay charts Matthews' ambiguous and difficult role during his stay in Revolutionary Paris, and offers a plausible account of how the strain of conducting peace negotiations between the two countries, whose relationship was rapidly worsening, led to the eventual onset of mental illness. Jay also offers fresh insights into the role of the medical specialists and other significant characters in Matthews' life. Haslam's professional ambition is nicely analysed. The doctor's role in the articulation of Matthews' delusion is perceptively discussed. Accounts of other supporting casts are seamlessly woven into the narrative.

The major subject in Jay's book is, inevitably, the inner world of Matthews, the air loom and its gangs. Jay's astute analysis of the historical context in which Matthews forged the delusion is undoubtedly the highlight of the book. Jay correctly argues that Matthews drew images from the hotly contested frontiers of scientific research in the late eighteenth century. The politically charged pneumatic chemistry was one of the latest scientific vogues incorporated into Matthews' delusion. More important was the immensely popular but deeply controversial practice of mesmerism, through which the late Enlightenment and Romantic anxiety about the self infiltrated into Matthews' famous delusion of the air loom and its gangs of operators. Concealed in various London sites, including the grounds of Bethlem Hospital, or so Matthews believed, these air looms were nefariously employed to manipulate the minds of all and sundry, from politicians to hospital staff and patients. Cartesian cogito, which had given the ultimate stability to the self, evaporated into bundles of sentient fibres that were affected through magnetic fluid permeating the space between the self and others. The pathologies of politics, too, crystallized into Matthews' delusion. For conservatively-minded political commentators, the seemingly random currents of the French Revolution and the ultimate destruction of monarchy and church were actually the product of the design of a handful of vicious schemers from the Masonic movement. Politicians, according to these 
observers, were no longer legitimate decision-makers but the mere puppets of plotters. Matthews' delusion chimed with such conspiracy theories: people, including politicians, were not acting volitionally but were manipulated by the vicious gang. The inner world of Matthews was thus the harbinger of the morbid imagination of conspiracy theory, which, from time to time, raised its ugly head in the nineteenth and twentieth centuries. Last but not least, Jay directs our attention to the fact that the centrepiece of Matthews' delusion was a machine. This was, according to Jay, a prescient insight into the momentous change in the worldview of Western civilization in the last two centuries: machine, not God, became the centre of the universe, and individuals became a subservient part of the mechanized great chain of beings. At the beginning of the nineteenth century, Matthews imagined himself to be incorporated into the scheme of a machine. Jay thus finds in Matthews' delusion a dark prophecy of eerie anxieties of the nineteenth and twentieth centuries, when the ownership of one's own mind and consciousness has become ambiguous, the legitimacy of politics has been doubted, and the boundary and hierarchy between human and machine has been destabilized. In a word, Jay's Matthews is a mad prophet of the modern and post-modern anxieties of civilization. Just as Eric Santner's My Own Private Germany (1996) explores the pathogenesis of fin-de-siècle Germany through the window of the inner world of Schreber's delusion, Jay's The Air Loom Gang detects the psychic disjunction latent in the French and Industrial Revolutions. Matthews' pneumatic mind-controlling machine was, according to Jay, an ominous sign of the dark side of the age of the Dual Revolution. Academic historians of mental illness might prefer more articulated and less sweeping approaches, like the one adopted by Ian Hacking in his concept of the ecological niche of mental diseases, elaborated in his Mad Travellers (1997). In particular, one would have liked Jay to investigate similar delusions among other patients. Nevertheless, Jay has proposed an ambitious, comprehensive and extremely interesting interpretation of Matthews and his delusion, and of schizophrenia in general.

Jay portrays Matthews' inner world as inhabited by de-personalized characters, who were only half-human or half-self. In contrast, Hollingshead's novel presents a markedly different set of characters. The novel features humans, with solid personal identities with emotions, beliefs and actual lives. The story, consisting of a series of narratives of events seen through the eyes of Haslam, Matthews and Margaret, his wife, generally follows real historical events closely, with poetic licence sparingly but effectively exercised. The inclusion of Margaret adds much human emotion to the whole story: a wife who remained supportive to the mad husband, absent for years across the Channel and then confined in Bethlem. Hollingshead lets her infuse hope, anxiety, trust and love into the story. Haslam, too, becomes much more humanized and nuanced in Hollingshead's account. The apothecary is less exclusively a careerist, custodian and medical scientist hungry for professional 
recognition: as well as worrying over the disorganization at the ancient institution for which he worked, he is also a family man, a caring husband and a loving father. Most interestingly, Hollingshead's Matthews emits a curious sense of ordinariness. Not that his Matthews is normal. Hollingshead makes his Matthews live in the world tightly controlled by the air loom and its gang: his Matthews consistently refers to Haslam as 'Jack' (the schoolmaster), and when Samuel Tuke is introduced into the novel and allowed to meet Matthews, the patient recognizes the famous reformer in lunacy as 'Bill the King', the chief of the gangs. Indeed, Hollingshead's Matthews is arguably madder than that of Jay, who assumes a more cautious attitude to the insanity of the subject. Nevertheless, Hollingshead's Matthews does not convey the horror of living a machine-directed life, or the agonizing sense of losing ownership of one's ideas. Hollingshead narrates the story of paradoxically ordinary characters trying to live the life of a modern family in an impossible situation, practising affective individualism in a surreal setting. Haslam showing his little son the brain of the cadaver is the best example.

The two books under review therefore represent very different pictures of James Tilly Matthews, his confinement and his delusion. Jay makes his subject a prophet of the spooky and pathological undercurrents of modern and post-modern civilization, the way leading to Big Brother, to the hysteria over a Zionist conspiracy, or to the mechanized dystopia à la Matrix. Hollingshead, on the other hand, attempts to infuse humanity into the bizarre world of Matthews and the cold-blooded business of his confinement. While Jay's ultimate aim is to debunk the normalcy of modern and postmodern civilization, Hollingshead's is to humanize and domesticate the world of schizophrenics and their control. However, we would miss the point of both authors if we try to decide which picture is 'right'. One cannot decide, not because we are now on the post-modern bandwagon that rejects the notion of historical veracity, but because the two pictures are the opposite sides of the same coin. The contrast of the two works originates, I would like to argue, from the deep-seated ambiguity of mental illness and the enterprise of psychiatry. Almost from time immemorial, we have the powerful dual myths of sanity in madness and the world as a great Bedlam: ramblings of madness reveal truth hidden to us normals, who actually inhabit a world that has turned mad. Jay's exegesis is practised according to this line of logic, listening to the prophesy of disjointed modernity in Matthews. On the other hand, at least as powerful a myth since the nineteenth century tells the humanitarian creed: mad people are profoundly like us and should be treated as such. Hollingshead's attempt to domesticate Matthews and his environs represents the continuation of this myth. Put together, those myths point towards a profound ambiguity in the label of mental illness and the business of psychiatry. Perhaps we are lucky to have two books which have thrown light on the two aspects of the ambiguity of mental illness and have made us recognize yet again how ambiguous a subject we are dealing with. 
Despite such ambiguity, the two books have brought a hope to us all. Not the hope of solving these age-old riddles but that of asking more questions. The works of Jay and Hollingshead suggest that there are many patients who wait to be excavated. Every reader of the journal might have his or her 'pet' historical patient, now dormant in the archives of psychiatric hospitals or in the private papers of psychiatric practitioners. Despite recent vigorous attempts to practise a patient-centred history of psychiatry, most notably by Allan Beveridge and others, we still suffer from a shortage of patients' views. No doubt readers of this journal could name dozens of psychiatrists - but how many 'famous' patients can we name? Ironically, the history of patients published to date, lavishing attention on just a handful of patients such as Schreber, is far more elitist than our history of doctors. The two works reviewed here have firmly established Matthews in our list of those important patients about whom we have detailed knowledge. One craves for more.

\section{References}

Hacking, I. (1997) Mad Travellers (Charlottesville and London: University Press of Virginia). Haslam, J (1810/1988) Illustrations of Madness, edited by Roy Porter (London: Routledge). Santner, E. (1996) My Own Private Germany (Princeton, NJ: Princeton University Press). 